\title{
EDITORIAL
}

\section{Trials on oxygen supplementation in sepsis: better late than never}

\author{
Anders Perner ${ }^{1 *} \mathbb{D}$, Audrey De Jong ${ }^{2}$ and Manu Shankar-Hari ${ }^{3,4}$
}

(c) 2019 Springer-Verlag GmbH Germany, part of Springer Nature

Oxygen supplementation is one of the most frequently used interventions in critically ill patients. In addition, most ICU patients with sepsis receive oxygen supplementation irrespective of the presence or absence of hypoxia [1]. In the 2016 iteration of the Surviving Sepsis Campaign (SSC) guideline [2], there was no guidance on the use of supplementary oxygen or on oxygenation targets for these patients, alongside recommendations for further research [3].

To our knowledge, at least one randomised trial has been conducted on oxygen therapy in sepsis, the Hyper2S-trial [4]. This two-by-two factorial, multicentre, randomised trial allocated mechanically ventilated patients with septic shock to an $\mathrm{FiO}_{2}$ at 1.0 (hyperoxia) vs. an $\mathrm{FiO}_{2}$ targeting an oxygen saturation of $88-95 \%$ (normoxia) during the first $24 \mathrm{~h}$. The other allocation was to isotonic vs. hypertonic saline infusion. The trial was stopped prematurely for safety reasons when 442 of the planned 800 patients had been enrolled. The primary outcome, 28-day mortality, had occurred in $43 \%$ in the hyperoxia group vs. $35 \%$ in the normoxia group (hazard ratio $1.27,95 \%$ CI $0.94-1.72 ; p=0.12$ ). The incidence of serious adverse events, including atelectasis and intensive care unit-acquired weakness, appeared to be higher in the hyperoxia vs. the normoxia group. While this caused some concern, the use of $\mathrm{FiO}_{2}$ at 1.0 in clinical care of patients with sepsis appeared to be quite rare; the baseline $\mathrm{FiO}_{2}$ in two sepsis trials combined $(n=1770)$ was reported to be 0.51 (inter-quartile range $0.40-0.70$ ) [1].

The results of the Hyper2S trial did support the notion of harm from more liberal use of oxygen as observed in

\footnotetext{
*Correspondence: anders.perner@regionh.dk

${ }^{1}$ Dept. of Intensive Care, Copenhagen University Hospital, Copenhagen, Denmark
}

Full author information is available at the end of the article observational studies in general ICU patients $[5,6]$ and in those with sepsis [1]. A post hoc analysis of Hyper2Strial highlighted potential harm only in patients meeting the sepsis-3 defined septic shock, which is hypotension requiring vasopressor therapy and raised lactate concentrations. The implication being harmful effects of oxygen may be exaggerated in sepsis patients with evidence of cellular and metabolic abnormalities [7], likely to be mediated by reactive oxygen species, in the context of impaired mitochondrial function and lower antioxidant concentrations seen in sepsis [8]. The other larger trial done in ICU patients, the OXYGEN-ICU trial [9], included 480 adult ICU patients expected to stay at least $72 \mathrm{~h}$, among whom $40 \%$ had documented infection at baseline. Again, the results suggested that higher use of oxygen caused harm, but the single-center design and the stopping of the trial after an unplanned interim analysis hamper the interpretation.

On that background, it is more than welcome to read the publication of the sub-group of patients with sepsis from the ICU-ROX trial in Intensive Care Medicine [10]. The ICU-ROX trial was a multicentre randomized trial allocating 1000 adult ICU patients who were expected to be mechanically ventilated for $>24 \mathrm{~h}$ to receive conservative or usual oxygen therapy. In the conservativeoxygen group, the upper limit of $\mathrm{SpO}_{2}$ was $97 \% ; \mathrm{FiO}_{2}$ was decreased to 0.21 if the $\mathrm{SpO}_{2}>90 \%$. In the usualoxygen group, there were no specific measures limiting the $\mathrm{FiO}_{2}$ or the $\mathrm{SpO}_{2}$. In the full trial cohort, there was no difference in the number of ventilator-free days, which was the primary outcome. There were four predefined subgroup analysis, among which patients with suspected hypoxic-ischemic encephalopathy appeared to have worse outcome with usual oxygen therapy. The present study is a post hoc sub-group analysis of 251 patients adjudicated to have sepsis at baseline. There was no statistically significant treatment effect heterogeneity

\section{Springer}


Table 1 Ongoing ICU trials likely randomising subgroups of patients with sepsis to higher vs. lower oxygenation targets

\begin{tabular}{|c|c|c|c|c|c|c|}
\hline Trial acronym & Identifier & Population & Sample size & Higher $\mathrm{O}_{2}$ target & Lower $\mathrm{O}_{2}$ target & Status \\
\hline HOT-ICU & NCT 03174002 & $\begin{array}{l}\text { ICU patient with acute } \\
\text { hypoxia within } 12-\mathrm{h} \\
\text { of ICU admission }\end{array}$ & 2928 & $\mathrm{PaO}_{2} 90 \mathrm{mmHg}$ & $\mathrm{PaO}_{2} 60 \mathrm{mmHg}$ & $\begin{array}{l}\text { Recruiting-estimated } \\
\text { completion June } \\
2020 \\
\text { Interim analysis past } \\
\text { (50\% of patients) }\end{array}$ \\
\hline $\mathrm{O} 2-\mathrm{ICU}$ & NCT 02321072 & $\begin{array}{l}\text { ICU patients with } \geq 2 \\
\text { positive SIRS-criteria } \\
\text { and an expected ICU } \\
\text { stay }>48 \mathrm{~h}\end{array}$ & 385 & $\begin{array}{l}\mathrm{PaO}_{2} 120(105-135) \\
\mathrm{mmHg}\end{array}$ & $\begin{array}{l}\mathrm{PaO}_{2} 75(60-90) \\
\mathrm{mmHg}\end{array}$ & $\begin{array}{l}\text { Recruiting-estimated } \\
\text { completion Dec } \\
2019\end{array}$ \\
\hline LOCO2 & NCT 02713451 & $\begin{array}{l}\text { ICU patients with ARDS } \\
\text { ventilated }<12 \mathrm{~h}\end{array}$ & 206 planned 850 & $\mathrm{PaO}_{2}(90-105) \mathrm{mmHg}$ & $\mathrm{PaO}_{2}(55-70) \mathrm{mmHg}$ & $\begin{array}{l}\text { Terminated for safety } \\
\text { reasons }\end{array}$ \\
\hline TOXYC & NCT 03287466 & $\begin{array}{l}\text { ICU patients who } \\
\text { are expected to be } \\
\text { mechanically venti- } \\
\text { lated }>24 \mathrm{~h}\end{array}$ & 60 & Standard care & $\mathrm{SpO}_{2}(88-92 \%)$ & $\begin{array}{l}\text { Recruiting-estimated } \\
\text { completion Dec } \\
2019\end{array}$ \\
\hline
\end{tabular}

ARDS acute respiratory distress syndrome, SIRS systemic inflammatory response syndrome; Data obtained from clinicaltrials.gov (Webpage accessed on 11 November 2019)

between conservative vs. usual-care oxygen therapy on 90-day mortality (36.2\% vs. $29.2 \%$ [absolute difference, $7.0 \%$ points; $95 \% \mathrm{CI},-4.6$ to 18.6$]$; $p$ value for interaction $=0.35$ for sepsis vs. non-sepsis). None of the secondary outcomes differed between group, but all point estimates favoured usual-care oxygen. The investigators conclude that clinically important harm is possible with conservative oxygen therapy in patients with sepsis, but benefit cannot be excluded. The interpretation of these findings is hampered by the post hoc design, the lack of stratification for sepsis at allocation, in fact many of the patients presented had to identified in registers post hoc, the small samples size as acknowledged by the investigators and use of 90-day mortality as the outcome instead of the primary outcome of ventilator-free days used in the ICU-ROX trial.

Clearly these results call for more trials on oxygen in this patient group as suggested by the ICU-ROX investigators. There are several ongoing randomized trial enrolling ICU patients to different oxygenation strategies (Table 1); several of these trials are likely enrolling at fair number of patients with sepsis. However, none of the trials are focused specifically on sepsis; the enrol patients with acute hypoxia, systemic inflammatory response syndrome or ARDS (Table 1). And none of the ongoing trials are likely to provide a large sub-group of patients with sepsis to substantially increase the certain of the effect estimates observed in the ICU-ROX sub-group; the HOT-ICU trial is the only large trial ongoing, but the presence of sepsis is not registered at baseline in that trial [11]. A large subgroup of patients with sepsis will likely be included in the MEGA-ROX trial planned by the ICU-ROX investigators. When finalised, MEGA-ROX will have enrolled 40,000 ICU patients and likely provide reliable estimates on the effects of conservative oxygen therapy in sepsis.

\section{How much oxygen shall we give to patients with sepsis until further evidence is available?}

Oxygen is a drug-as such it has beneficial effects and side-effects. The balance between the benefit and harm of higher vs. lower targets for oxygen supplementation in patients with sepsis is still unknown. Until we have better evidence from large randomized trials, a strategy that avoids both hypoxia and hyperoxia may be aimed for. Such a strategy was recommended in a recent clinical practice guideline on oxygen therapy in acutely ill medical patients. The strong recommendation was to aim for peripheral capillary oxygen saturation $\left(\mathrm{SpO}_{2}\right)$ of $\leq 96 \%$, for acutely ill medical patients receiving oxygen therapy. The authors also highlight that it is reasonable to aim for a target range of $90-94 \%$ in most patients [12].

\begin{abstract}
Author details
${ }^{1}$ Dept. of Intensive Care, Copenhagen University Hospital, Copenhagen, Denmark. ${ }^{2}$ Department of Anesthesia and Intensive Care Unit, Regional University Hospital of Montpellier, St-Eloi Hospital, PhyMedExp, Université de Montpellier, INSERM, CNRS, Montpellier, France. ${ }^{3}$ Department of Critical Care Medicine, Guy's and St Thomas' NHS Foundation Trust, London SE17EH, UK. ${ }^{4}$ School of Immunology and Microbial Sciences, Kings College, London SE1 9RT, UK.
\end{abstract}

\section{Author contributions}

AP wrote the first draft. All authors contributed to the critical revision of the manuscript for important intellectual content.

Compliance with ethical standards

\section{Conflicts of interests}

AP is in the steering committee of the HOT-ICU trial and receives research funding from the Innovation Foundation and Novo Nordisk Foundation, Denmark. This work was supported by the National Institute for Health Research Clinician Scientist Award (CS-2016-16-011 for MSH). The views expressed in 
this publication are those of the authors and not necessarily those of the National Health Service, the National Institute for Health Research, or the Department of Health and Social Care. All authors are on the Editorial Board for ICM and declare no other competing interests.

\section{Publisher's Note}

Springer Nature remains neutral with regard to jurisdictional claims in published maps and institutional affiliations.

Received: 12 November 2019 Accepted: 16 November 2019

Published online: 26 November 2019

\section{References}

1. Dahl RM, Gronlykke L, Haase N, Holst LB, Perner A, Wetterslev J, Rasmussen BS, Meyhoff CS, Trial S, investigators TT (2015) Variability in targeted arterial oxygenation levels in patients with severe sepsis or septic shock. Acta Anaesthesiol Scand 59:859-869

2. Rhodes A, Phillips G, Beale R, Cecconi M, Chiche JD, De Backer D, Divatia J, Du B, Evans L, Ferrer R, Girardis M, Koulenti D, Machado F, Simpson SQ, Tan CC, Wittebole X, Levy M (2015) The Surviving Sepsis Campaign bundles and outcome: results from the International Multicentre Prevalence Study on Sepsis (the IMPreSS study). Intensive Care Med 41:1620-1628

3. Coopersmith CM, De Backer D, Deutschman CS, Ferrer R, Lat I, Machado FR, Martin GS, Martin-Loeches I, Nunnally ME, Antonelli M, Evans LE, Hellman J, Jog S, Kesecioglu J, Levy MM, Rhodes A (2018) Surviving sepsis campaign: research priorities for sepsis and septic shock. Intensive Care Med 44:1400-1426

4. Asfar P, Schortgen F, Boisrame-Helms J, Charpentier J, Guerot E, Megarbane B, Grimaldi D, Grelon F, Anguel N, Lasocki S, Henry-Lagarrigue M, Gonzalez F, Legay F, Guitton C, Schenck M, Doise JM, Devaquet J, Van Der Linden T, Chatellier D, Rigaud JP, Dellamonica J, Tamion F, Meziani F, Mercat A, Dreyfuss D, Seegers V, Radermacher P, Investigators HS, network $\operatorname{Rr}$ (2017) Hyperoxia and hypertonic saline in patients with septic shock (HYPERS2S): a two-by-two factorial, multicentre, randomised, clinical trial. Lancet Respir Med 5:180-190

5. Helmerhorst HJ, Schultz MJ, van der Voort PH, Bosman RJ, Juffermans NP, de Wilde RB, van den Akker-van Marle ME, van Bodegom-Vos L, de Vries
M, Eslami S, de Keizer NF, Abu-Hanna A, van Westerloo DJ, de Jonge E (2016) Effectiveness and clinical outcomes of a two-step implementation of conservative oxygenation targets in critically ill patients: a before and after trial. Crit Care Med 44:554-563

6. de Jonge E, Peelen L, Keijzers PJ, Joore H, de Lange D, van der Voort PH, Bosman RJ, de Waal RA, Wesselink R, de Keizer NF (2008) Association between administered oxygen, arterial partial oxygen pressure and mortality in mechanically ventilated intensive care unit patients. Crit Care 12:R156

7. Demiselle J, Wepler M, Hartmann C, Radermacher P, Schortgen F, Meziani F, Singer M, Seegers V, Asfar P, investigators HS (2018) Hyperoxia toxicity in septic shock patients according to the Sepsis-3 criteria: a post hoc analysis of the HYPER2S trial. Ann Intensive Care 8:90

8. Brealey D, Brand M, Hargreaves I, Heales S, Land J, Smolenski R, Davies NA Cooper CE, Singer M (2002) Association between mitochondrial dysfunction and severity and outcome of septic shock. Lancet 360:219-223

9. Girardis M, Busani S, Damiani E, Donati A, Rinaldi L, Marudi A, Morelli A, Antonelli M, Singer M (2016) Effect of conservative vs conventional oxygen therapy on mortality among patients in an intensive care unit: the oxygen-ICU randomized clinical trial. JAMA 316:1583-1589

10. Young P, Mackle D, Bellomo R, Bailey M, Beasley R, Deane A, Eastwood G, Finfer S, Freebairn R, King V, Linke N, Litton E, McArthur C, McGuinness S, Panwar R, the ICU-ROX Investigators the Australian New Zealand Intensive Care Society Clinical Trials Group (2019) Conservative oxygen therapy for mechanically ventilated adults with sepsis: a post hoc analysis of data from the intensive care unit randomized trial comparing two approaches to oxygen therapy (ICU-ROX). Intensive Care Med. https://doi. org/10.1007/s00134-019-05857-x

11. Schjorring $\mathrm{OL}$, Perner $A$, Wetterslev J, Lange T, Keus F, Laake JH, Okkonen M, Siegemund M, Morgan M, Thormar KM, Rasmussen BS, Investigators $\mathrm{H}-\mathrm{I}$ (2019) Handling Oxygenation Targets in the Intensive Care Unit (HOTICU)-Protocol for a randomised clinical trial comparing a lower vs a highe oxygenation target in adults with acute hypoxaemic respiratory failure. Acta Anaesthesiol Scand 63:956-965

12. Siemieniuk RAC, Chu DK, Kim LH, Guell-Rous MR, Alhazzani W, Soccal PM, Karanicolas PJ, Farhoumand PD, Siemieniuk JLK, Satia I, Irusen EM, Refaat MM, Mikita JS, Smith M, Cohen DN, Vandvik PO, Agoritsas T, Lytvyn L, Guyatt GH (2018) Oxygen therapy for acutely ill medical patients: a clinical practice guideline. BMJ 363:k4169 